\title{
Nutrition-related problems of middle age
}

\section{By H. N. Munro, USDA Human Nutrition Research Center on Aging, Tufts University, 71 I Washington Street, Boston, MA 02 I I I, USA}

In a review of nutrition and ageing (Munro, 198I), it was suggested that research on this topic can be divided into three headings. First, there are the changes in body composition and physiological function that occur progressively throughout adult life. In most cases it is uncertain whether these processes are responsive to nutritional status. Second, some chronic diseases and disabilities of adults increase with age; in some cases, such as atherosclerosis, there is controversial evidence relating the progress of this condition to nutrient intakes. Finally, there is the tendency of adults to reduce their total food intake progressively as they get older. This usually results in diminished intakes of most nutrients. In most cases, our ignorance of the needs of adults for individual nutrients as they get older does not allow us to say whether this reduction in intake falls below the amount necessary to maintain optimum body function.

This paper will deal with each of these aspects of the ageing process. It will emphasize that middle age is a time to establish health-related habits (including nutritional) in preparation for old age. Although emphasis tends to be placed on the age-associated diseases of adults (atherosclerosis, cancer, etc.), the progressive erosion of tissue function, though less dramatic, is commonly responsible for the eventual disabling of the individual. Katz et al. $(1983)$ have recently used life-table techniques to estimate the expected years of functional well-being remaining to residents of Massachusetts at various ages from 65 years onwards. Using the criteria of unassisted rising from bed, bathing, dressing and eating, they found that men of $65-69$ years averaged $9 \cdot 3$ more years of independent living and a further 3.8 years of dependence, while for women of $65-69$ years there remained 10.6 years of independent living and 8.9 years of dependence. An important question is thus the extent to which life-style factors, including nutrition, during the period preceding old age can extend the period of independent living.

\section{Changes in body composition and tissue function during middle age}

The composition of the body changes continuously through adult life. Over the adult life-span, there is a progressive reduction in body content of ${ }^{40} \mathrm{~K}$, representing loss of lean body mass (Forbes, 1976) with a compensatory accumulation of adipose tissue. Comparison of this ${ }^{40} \mathrm{~K}$ loss with a reduction in body nitrogen content measured by neutron activation has been studied at various ages by Cohn et al. (1980). Since muscle is richer in ${ }^{40} \mathrm{~K}$ than are other major tissues, these two measurements allowed the investigators to demonstrate that 
most of the loss of lean body mass represents muscle, a conclusion confirmed by the reduced urinary output by older people of two metabolites coming from muscle, namely creatinine and 3-methylhistidine (Munro \& Young, 1978).

It might be thought that the effect of nutrition on this loss of lean body mass could be studied by $\mathrm{N}$ balance, since the body is steadily losing protein. However, as pointed out elsewhere (Munro, 1983), $\mathrm{N}$ balance is too insensitive. Thus Steen et al. (1979) reported a longitudinal study of the ${ }^{40} \mathrm{~K}$ content of a group of men between 70 and 75 years of age. These measurements show that the subjects lost I kg lean body mass during this 5 -year period. This is equivalent to a negative $\mathrm{N}$ balance of $20 \mathrm{mg} \mathrm{N} / \mathrm{d}$, whereas approximately $500 \mathrm{mg} \mathrm{N}$ represents the minimum daily $\mathrm{N}$ balance difference one could hope to discriminate. Such insensitivity would mask gross changes in the rate of loss of lean body mass on different diets.

Although most organs do not lose mass so extensively as does muscle, Shock (1970) has demonstrated that all organs and systems undergo progressive and, in some cases, extensive impairment of function with ageing. As every sports fan knows, these changes in body composition and organ function are already well established before 65 years of age, and are thus phenomena of middle age. In most cases, we have no evidence linking rate of loss of function of an organ to any nutrient or combination of nutrients. Nevertheless, Meyer et al. (1983) have argued that a high intake of protein accelerates loss of kidney function.

The most extensively and successfully studied relationship between long-term dietary patterns and age-related changes in body composition and function is provided by loss of bone density with age. The onset of this change is variously put at 20 years (Riggs et al. 1982 ) or 40 years (Garn, I978), but all agree that women are more extensively affected than men by rapid loss of calcium experienced by some women during the first $15^{-20}$ years after the menopause. The process of bone loss that can eventually end in osteoporotic fracture of the spine or the long bones is thus already well established in middle life. Nutrients considered to be involved include $\mathrm{Ca}$, phosphorus, vitamin $\mathrm{D}$ and protein. A panel of experts has recently evaluated the role of $\mathrm{Ca}$ in the maintenance of bone health in adults (Heaney et al. 1982). They concluded from extensive surveys of $\mathrm{Ca}$ intake by US populations studied during the past decade that intakes by adults were much lower than by teenagers. $\mathrm{Ca}$ intakes were especially low for women as compared to men between the ages of 20 and 50 years. It is important to recognize that the period of late adolescence and early adult life may be the most important time to ensure an adequate intake of $\mathrm{Ca}$ in order to provide a sufficient bone density to compensate for later bone losses. This is shown clearly by a study (Matkovic et al. 1979) of populations in two regions of Yugoslavia, one with a low intake of $\mathrm{Ca}(500 \mathrm{mg} / \mathrm{d}$ at age $40-42$ years) and the other a high intake ( $110 \mathrm{mg} / \mathrm{d}$ at that age). Already, in early adult life, bone mass was greater in men and women in the high-Ca district. In subsequent years, bone density declined in parallel in both districts but, because of the lower bone density of young adults in the low-Ca district, they reached the critical level for fracture at an earlier age than did the population of the high-Ca area. Garn (1978) has drawn attention to a similar phenomenon among American 
blacks who enter adult life with denser bones. For this reason, clinical experience shows that blacks in the US seldom develop osteoporotic fractures.

A number of studies have been made on the response of bone mass to dietary supplements of $\mathrm{Ca}$ given over adequately long periods. Studies on women undergoing postmenopausal bone loss are particularly pertinent to middle-aged nutritional habits. Horsman et al. (1977) found that raising total $\mathrm{Ca}$ intake to $1.5 \mathrm{~g} / \mathrm{d}$ over a 3 -year period reduced loss of arm-bone density by postmenopausal women. This has been essentially confirmed by a similar study, also at an intake of I. $5 \mathrm{~g} \mathrm{Ca} / \mathrm{d}$ (Recker et al. 1977). The benefit to bone mass of giving oestrogens to postmenopausal women with osteoporosis has also been established; Gallacher (1976) and Heaney et al. (1978) have shown that $\mathrm{Ca}$ balance can be maintained with much less dietary $\mathrm{Ca}$ in oestrogen-treated patients (mean about $\mathrm{I} . \circ \mathrm{g} \mathrm{Ca} / \mathrm{d}$ ) than in untreated controls (mean about $1.5 \mathrm{~g} / \mathrm{d}$ ). In a recent review of their experiences with oestrogen treatment of postmenopausal osteoporosis, Horsman et al. (1983) conclude that supplemental Ca may allow the optimal oestrogen dose to be reduced, thus diminishing the risks of oestrogen administration.

Other factors affect the integrity of bone. Experimental studies with formula diets show that selectively increasing the protein intake of young adults results in a less-favourable $\mathrm{Ca}$ balance (e.g. Anand \& Linkswiler, 1974), an effect due to less efficient reabsorption of $\mathrm{Ca}$ by the renal tubules. Spencer et al. (1978) claim that natural sources of protein, such as meat, contain enough $P$ to offset this calciuric action of dietary protein. On the other hand, Heaney $\&$ Recker ( 1982 ) concluded from an analysis of $\mathrm{Ca}$ balance in perimenopausal women, in relation to their normal intakes of various nutrients, that the action of $P$ was not large enough to offset the effect of protein. Regarding dietary fibre, Heaney et al. (1982) conclude that high intakes of fibre and phytate can impair $\mathrm{Ca}$ absorption, but not at the levels of fibre consumption provided by most Western diets. The contribution of vitamin $\mathrm{D}$ deficiency to metabolic bone disease is uncertain. Florid deficiency occurs as osteomalacia, which is commoner in old people in Europe than in the US, where fortification of milk and margarine with ergocalciferol and greater exposure to the sun adds protection (Parfitt et al. 1982). Finally, exercise can make an important contribution to bone strength. Aloia et al. (1978a) report that middle-aged marathon runners have ir $\%$ more bone $\mathrm{Ca}$ than do sedentary contemporaries. This is not entirely due to increased deposition of skeletal $\mathrm{Ca}$ as young adults, since it has been shown that middle-aged women can reverse the skeletal loss of $\mathrm{C}_{2}$ by exercising for 8 months (Krølner et al. 1983) or I year (Aloia et al. 1978b), and elderly women for 3 years (Smith et al. 1981).

\section{Dietary factors in middle age related to hypertension}

For more than three decades, the role of nutrition in cardiovascular disease has generated a large amount of discussion. From the evidence accumulated, the role of nutrition in the control of blood pressure has been selected here. Measurement of blood pressure is the simplest non-invasive technique to apply to large populations for the assessment of cardiovascular function. Hypertension is the foremost cause 
of cardiovascular disease and stroke and is thus one major risk factor in predicting cardiovascular disease. For example, in the Framingham study an increase in systolic blood pressure from 105 to $195 \mathrm{~mm} \mathrm{Hg}$ by itself or in combination with one or more of the other risk factors doubled the chances of a man of 40 years developing a major cardiovascular episode in the next 8 years (Kannel, 1977).

Obesity is a well-known factor in the development of hypertension (Van Itallie, 1978). An analysis of the data provided by the Framingham study (Havlik et al. 1983) indicates that the correlation between indices of obesity (weight and Quetelet index) and blood pressure was strongest in early adulthood and declined thereafter. In this study also, rate of weight gain in early adult life was found to be a good predictor of blood pressure. In a long-term study of air pilots who were initially normotensive and slim, the greatest increase in blood pressure occurred in those who increased their body-weight between 24 and 30 years of age (Harlan et al. I973). Van Itallie (1978) cites other evidence confirming that obesity acquired between the ages of 20 and 40 years carries most danger for cardiovascular disease. Kannel \& Gordon (1979) comment 'because it reversibly promotes atherogenic traits like hypertension, diabetes and hyperlipidemia, reduction of overweight is probably the most important hygienic measure (aside from the avoidance of cigarettes) available for the control of cardiovascular disease.' The control of body-weight through diet and exercise during early adult life and middle age thus appears to be one desirable method of reducing the occurrence of hypertension. In an appraisal of the evidence linking excess energy intake to disease, Van Itallie \& Hirsch (1978) comment that 'the association (of obesity) with blood pressure is close: blood pressure often falls concomitantly with weight reduction in hypertensive individuals'.

Recently, the studies of Iacono and his colleagues have drawn attention to dietary fat as an energy source specifically related to hypertension. Their subjects included North Americans, Italians and Finns aged 30-60 years (Iacono et al. 1981; Puska et al. 1983). In the first of these publications, they demonstrated a reduction in systolic and diastolic blood pressure, especially in hypertensive subjects, when they were transferred from high-fat diets $\left(35^{\circ}-45^{\circ} \mathrm{g} / \mathrm{kg}\right)$ providing mostly saturated fat (ratio, polyunsaturated:saturated fatty acids (P:S) 0.3 ), to lower-fat diets $\left(25^{\circ} \mathrm{g} / \mathrm{kg}\right)$ with a high P:S value (about I $\mathrm{O}$ ) for periods of $30-40 \mathrm{~d}$. In the later publication, they describe a 6-week intervention study in Finland where couples living in rural communities on high-fat diets with low $P: S$ values were given diets providing $23 \%$ fat energy with a P:S value of $1 \cdot 0$ for 6 weeks, followed by a return to their traditional diet. Both systolic and diastolic blood pressures fell during the period of low-fat intake. A control group on their normal unrestricted diet throughout and another control group who only restricted salt intake showed no changes in blood pressure. Although the interpretation of the effects of the low-fat diet is somewhat confounded by a simultaneous fall in energy intake in the Finnish experiment, the combined impact of these experiments justifies a longer-term study to test the permanence of the reduction in blood pressure. 
The failure of Puska et al. ( 1983 ) to observe a reduction in blood pressure when sodium intake (measured by urinary output) was reduced from I 70 to $77 \mathrm{mmol} / \mathrm{l}$ per $d$ is not surprising, since only a few $(9-20 \%)$ of the population show a hypertensive rise in blood pressure at customary Western intakes of salt (Tobian, 1983). Such susceptible persons should restrict $\mathrm{Na}$ intake to less than $60 \mathrm{mmol} / \mathrm{l}$ per d, whereas the other $80 \%$ of the population can easily tolerate $200 \mathrm{mmol} / 1$ ( $7 \mathrm{~g}$ salt) per d. The same lack of correlation between $\mathrm{Na}$ intake and incidence of hypertension emerges from the US Health and Nutrition Examination Survey (HANES). From analysis of these results on the food intake and incidence of hypertension of a cross-section of the US population, McCarron et al. (1983) have provided a comparison between intakes of certain nutrients by normotensive and hypertensive men and women examined. At age 35-54 years, average intakes of $\mathrm{Na}$ by hypertensive men and women did not differ from those of normotensives, and this was also true of protein and fat intake. However, intakes of $\mathrm{Ca}$ were 25 and $15 \%$ less for hypertensive men and women respectively, while potassium intakes were 15 and 10\% lower respectively. There is already literature suggesting that a high intake of $\mathrm{K}$ is protective against hypertension (Langford, 1983). Evidence supporting a protective effect of dietary $\mathrm{Ca}$ has been assembled by $\mathrm{McC}$ arron $(1983)$ but is challenged by others.

\section{Trends in nutrient intake during middle age}

The best-authenticated difference in nutrient need during adult life is for energy. Results collected in Scotland for both sexes and summarized by Munro (1964) and cross-sectional studies made at the Gerontology Center at Baltimore on US male executives (McGandy et al. 1966) agree in showing that energy intake declines throughout adult life. The Baltimore study shows that at 28 years these men needed $\times 1 \cdot 3 \mathrm{MJ}(2700 \mathrm{kcal}) / \mathrm{d}$, while at 65 years their intake had fallen to $9.6 \mathrm{MJ}$ $(2300 \mathrm{kcal}) / \mathrm{d}$, most of this reduction being due to less physical activity. As energy intake declines with age, so do the intakes of many nutrients. One would like to know whether such reductions in intake increase the risks of deficiency. Directly determined allowances for middle-aged and older adults are unavailable for most nutrients. Even so, on the basis of the HANES results for the US adult population, Heaney et al. (1982) comment that, 'after age 35 more than $75 \%$ of US women have $\mathrm{Ca}$ intakes less than the Recommended Dietary Allowance,' an allowance of $800 \mathrm{mg}$ daily that may itself be too low for this age-group (see p. 283).

The Baltimore group has been recalled for study twice over a subsequent 15-year period (Elahi et al. 1983). Their intakes of energy, protein, carbohydrate, saturated fat, polyunsaturated fat and cholesterol were analysed over this period in order to determine how far changes in intakes by individuals were due to ageing or to altered food preferences occurring throughout the whole population at different times. These results confirm that, during middle age ( 35 through 60 years), energy intake declines significantly with advancing years, as does total fat intake and cholesterol intake. On the other hand, intake of polyunsaturated fats and the P:S value were not affected by the ageing process, but both showed a significant 
increase between the first and last examination irrespective of age, implying that, at all ages, the population was consuming more unsaturated fat. Records of the US national food consumption since the beginning of the century (Munro, 1976) confirm that the increasing intake of fat is confined to vegetable fats, the main sources of polyunsaturated fatty acids.

\section{Conclusions}

Ageing is a continuous process throughout adult life, and middle age is the time at which these changes first make their effects apparent. During this period, significant loss of body $\mathrm{Ca}$ can precipitate osteoporotic fracture, for which increased $\mathrm{Ca}$ intake and physical exercise are preventive measures aimed at retaining bone $\mathrm{Ca}$. Nutritional and other life-style factors practised in early adult life and into middle age can also contribute to the prevention of hypertension. These factors include the avoidance of obesity through appropriate exercise and restriction of energy intake, and there is some evidence that energy from fat is more significant. Restriction of $\mathrm{Na}$ intake is beneficial to only a limited subsection of hypertensive adults. There is some evidence that an adequate intake of $\mathrm{K}$ is beneficial, and that hypertension is also commoner in individuals with low intakes of $\mathrm{Ca}$.

The common factors in these two conditions beginning in middle age, namely osteoporosis and hypertension, are adequacy of $\mathrm{Ca}$ intake and of exercise. The recommendation of regular exercise is also beneficial in stimulating energy intake without incurring obesity. The resulting greater intake of energy promotes intake of other nutrients, especially critical in the case of $\mathrm{Ca}$, zinc, folic acid, vitamin $\mathrm{B}_{6}$ and vitamin $\mathrm{E}$, the intake of which may decline in middle and old age below recommended dietary allowances on a low-energy intake. If the middle-aged pay attention to adequacy of nutrient intake and of physical activity, they can anticipate better retention of function and health as they pass into old age. In the words of Exton-Smith (1977), "the individual dietary patterns in the majority of old people remain similar to those which have been acquired by habits established at a younger age.'

The author is grateful to Dr B. Dawson-Hughes for help on the current status of nutrition and osteoporosis.

\section{REFERENCES}

Aloia, J. F., Cohn, S. H., Babu, T., Abesamis, C., Kalici, N. \& Ellis, K. (1978a). Metabolism 27, I 793-1 $79^{6}$.

Aloia, J. F., Cohn, S. H., Ostuni, J. A., Crane, R. \& Ellis, K. (1978b). Annals of Internal Medicine $89,35^{6-35^{8}}$.

Anand, C. R. \& Linkswiler, H. M. (1974). Fournal of Nutrition 104, 695-700.

Cohn, S. H., Vartsky, D., Yasumura, S., Sawitsky, A., Zanzi, I., Vaswani, A. \& Ellis, K. J. (1980). American fournal of Physiology 239, E529-E 530 . 
Elahi, V. K., Elahi, D., Andres, R., Tobin, J. D., Butler, J. D. \& Norris, A. H. (1983). Fournal of Gerontology 38, 162-180.

Exton-Smith, A. N. (1977). Proceedings of the Royal Society of Medicine 70, 615-621.

Forbes, G. B. (1976). Human Biology 48, 161-1 73 .

Gallagher, J. C. (1976). Cited by Heaney et al. (1982).

Garn, S. M. (1978). In Nutrition and the Aged, pp. 73-90 [F. A. Farmer, editor]. Alberta: University of Calgary Press.

Harlan, W. R., Oberman, A., Mitchell, R. E. \& Graybiel, A. (1973). Hypertension, Mechanisms and Management, pp. 85-91 [G. Onesti, K. E. Kim and J. H. Moyer, editors]. New York: Grume and Stratton.

Havlik, R. J., Hubert, H. B., Fabsitz, R. R. \& Feinlieb, M. (1983). Annals of Internal Medicine 98, $855-859$.

Heaney, R. P., Gallagher, J. C., Johnston, C. C., Near, R., Parfitt, A. M. \& Wheedon, G. D. (1982). American fournal of Clinical Nutrition 36, 987-1013.

Heaney, R. P. \& Recker, R. R. (1982). Fournal of Laboratory and Clinical Medicine 99, 46-55.

Heaney, R. P., Recker, R. R. \& Saville, P. D. (1978). Fournal of Laboratory and Clinical Medicine 92, $953-963$.

Horsman, A., Gallagher, J. C., Simpson, M. \& Nordin, B. E. C. (1977). British Medical fournal ii $789-792$.

Horsman, A., Jones, M., Francis, R. \& Nordin, C. (1983). New England Fournal of Medicine 309, ${ }^{1} 4^{\circ} 5^{-1} 4^{\circ} 7^{\circ}$

Iacono, J. M., Judd, J. T., Marshall, M. W., Canary, J. J., Dougherty, R. M., Mackin, J. F. \& Weinland, B. T. (1981). Progress in Lipid Research 20, 349-364.

Kannel, W. B. (1977). In Hypertension, Physiopathology and Treatment, pp. 888-910 [J. Genest, J. Koiw and E. Kuchel, editors]. New York: McGraw-Hill.

Kannel, W. B. \& Gordon, T. (1977). In Obesity in America, pp. 125-163 [G. A. Bray, editor]. NIH Publication no 79-359. Bethesda, MD: National Institutes of Health.

Katz, S., Branch, L. G., Branson, M. H., Papsidero, J. A., Beck, J. C. \& Greer, D. S. (1983). New England Journal of Medicine 309, $1218-1224$.

Krølner, B., Toft, B., Nielsen, S. P. \& Tondevold, E. (1983). Clinical Science 64, 54 I-546.

Langford, H. G. (1983). Annals of Internal Medicine 98, 770-772.

McCarron, D. A. (1983). Annals of Internal Medicine 98, 800-805.

McCarran, D. A., Stanton, J., Henry, H. \& Morris, C. (1983). Annals of Internal Medicine 98, 715-7I9.

McGandy, R. B., Barrows, C. H., Spanias, A., Meredith, A., Stone, J. L. \& Norris, A. H. (1966). fournal of Gerontology $21,5^{18-587}$.

Matkovic, V., Kostial, K., Simonovic, I., Buzina, R., Brodarec, A. \& Nordin, B. E. C. (1979). American fournal of Clinical Nutrition 32, 540-549.

Meyer, T. W., Anderson, S. \& Brenner, B. M. (1983). Annals of Internal Medicine $98,8_{32}-838$.

Munro, H. N. (1964). In Mammalian Protein Metabolism, vol. 2, pp. 3-39, [H. N. Munro and J. B. Allison, editors]. New York: Academic Press.

Munro, H. N. (1976). Fat Content and Composition of Animal Products, pp. 24-44. Washington DC: National Academy of Sciences.

Munro, H. N. (1981). British Medical Bulletin 37, 83-88.

Munro, H. N. (1983). In Nutritional Problems of the Elderly, pp. 61-74 [J. C. Somogyi and F. Fidanza, editors]. Basel: S. Karger.

Munro, H. N. \& Young, V. R. (1978). American fournal of Clinical Nutrition 31, 1608-1614.

Parfitt, A. M., Gallagher, J. C., Heaney, R. P., Johnston, C. C., Neer, R. \& Wheedon, G. D. (1982). American fournal of Clinical Nutrition 36, 1014-1031.

Puska, P., Iacono, J. M., Nissinen, A., Korhonen, H. J., Vertiainen, E., Pietinen, P., Dougherty, R., Leino, U., Mutanen, M., Moisio, S. \& Huttunen, J. (1983). Lancet i, I-5.

Recker, R. R., Saville, P. D. \& Heaney, R. P. (1977). Annals of Internal Medicine 87, 649-655.

Riggs, B. L., Wahner, H. W., Seeman, E., Offord, K. P., Dunn, W. L., Mazess, R. B., Johnson, K. A. \& Melton, L. J. (1982). Fournal of Clinical Investigation 70, 716-723.

Shock, N. (1 970). Fournal of the American Dietetic Association 56, 491-496.

Smith, E. L. Reddan, W. \& Smith, P. E. (1981). Medicine and Science in Sports and Exercise $13,60-64$. 
Spencer, H., Kramer, L., Osis, D. \& Norris, C. (1978). American fournal of Clinical Nutrition 31, $2167-2180$.

Steen, G. B., Isaksson, B. \& Svanberg, A. (1979). Fournal of Clinical and Experimental Gerontology 1, $185-200$.

Tobian, L. (1983). Annals of Internal Medicine 98, 729-734.

Van Itallie, T. B. (1978). American Yournal of Clinical Nutrition 32, 2723-2733.

Van Itallie, T. B. \& Hirsch, J. (1978). American Fournal of Clinical Nutrition 32, 2648-2653. 